\title{
Analisis Pemilihan Vendor Terbaik dalam Pengiriman Produk Minuman dalam Kemasan Menggunakan Metode AHP dan Topsis di PT CS2 Pola Sehat
}

\author{
Yonathan \\ Fakultas Teknik Industri Universitas Bina Nusantara, \\ tantan.jonathan@gmail.com
}

ARTICLE INFO

\section{Article History}

Received: 20 Pebruary 2020

Reviewed: 10 April 2020

Published: 30 April 2020

Available Online: 30 April

2020

Keywords:

Vendor selection, AHP, TOPSIS, Delivery.

\section{ABSTRACT}

\begin{abstract}
The process of distributing goods is precisely determined from the transportation service provider used. The transportation used will affect a supply chain can be fulfilled properly or not. The decision to choose the right vendor is based on the selection of criteria from each service provider that suits the needs of the company itself. The selection of the wrong criteria will have an impact on the services provided to customers, one of which is the delay factor. Delays that occur are dominated by shipping by land. Analysis of the selection of the right vendor is done by applying the AHP and TOPSIS methods. The criteria used consist of price, quality, delivery, flexibility and reliability. Application of AHP and TOPSIS methods will provide an assessment of each of these vendors so they can determine the best vendor. The selection of the best vendor starts from determining the weight of each predetermined criterion. Each criterion will be correlated with each other which will then be weighted by each criterion. The results of determining the best vendor are obtained with the highest weight value of 0.807 obtained by Japung using the TOPSIS method.
\end{abstract}

\section{A. PENDAhuluan}

Dalam sebuah proses pengadaan barang hal utama yang diperhatikan adalah pendistribusian barang tersebut. Pendistribusian akan melibatkan pihak ketiga sebagai jembatan untuk memenuhi suatu proses rantai pasok yang baik. Proses pendistribusian barang ditentukan dari kinerja tiap-tiap vendor logistik yang digunakan. Menurut Pujawan dan Mahendrawati (2010), kinerja vendor logistik perlu dimonitor secara terus menerus. Pelayanan jasa berperan penting untuk memenuhi kepuasan pelanggan. Untuk memenuhi pelayanan jasa yang baik maka perusahaan harus melakukan perbaikan dalam bidang rantai pasok dan logistik.

Saat ini, PT.CS2 Pola Sehat adalah salah satu perusahaan yang memproduksi minuman dalam kemasan yaitu air minum dalam kemasan botol PET dengan nama produk Crystaline. Dalam hal ini perusahaan harus melakukan evaluasi mengenai jasa ekspedisi yang digunakan dan melakukan pemilihan jasa ekspedisi yang terbaik.

Hal yang terjadi saat ini adalah adanya keluhan dari pelanggan terkait kinerja pelayanan yang diberikan. Tercatat mulai dari bulan Juli 2017 - Juli 2018 bahwa ada 7,050 mobil yang meluncur mengirimkan barang ke setiap wilayah tersebut dan tercatat ada 1,293 mobil yang di komplain oleh pelanggan dikarenakan adanya keterlambatan atau berarti sekitar $18 \%$ dari total armada yang sudah dikeluarkan. Keterlambatan yang terjadi akan mengakibatkan hilangnya omset (keuntungan) dikarenakan order permintaan dari customer akan dibatalkan secara otomatis. Hal ini tentu menjadi pertimbangan khusus bagi perusahaan untuk dapat memilih vendor yang terbaik agar masalah keterlambatan ini dapat teratasi.

\section{Outsourcing, Logistics And Third Party Logistic}

Menurut definisi Maurice Greaver (1999), outsourcing dipandang sebagai tindakan mengalih beberapa aktivitas perusahaan dan hak pengambilan keputusannya kepada pihak lain (outside provider), dimana tindakan ini terikat dalam suatu kontrak kerja sama. Sebenarnya outsourcing adalah pemindahan fungsi pengawasan dan pengelolaan suatu proses bisnis kepada perusahaan penyedia jasa. 
Untuk melakukan outsourcing, hal yang perlu diperhatikan adalah pembuatan kontrak antar kedua belah pihak (McCarthy \& Anagroustou, 2004). Dengan menggunakan outsourcing (pihak ketiga) diharapkan perusahaan dapat menjalankan produksinya tanpa memikirkan lagi tugas-tugas yang sudah diserahkan pada pihak outsourcing

Salah satu outsourcing yang menjadi banyak fokus inti dari perusahaan adalah pihak logistik (3PL). Menurut Vijayvargiya dan Dey (2010), Pihak logistik adalah pihak ketiga (3PL) yang menyediakan jasa logistik dengan suatu perusahaan penyedia produk atau jasa dengan kontrak tertentu. Menurut Ellram, Tate, \& Billington (2008), Kegiatan outsourcing diluar aktivitas utama perusahaan (produksi) akan meningkatkan kepuasan konsumen dan menurunkan resiko finansial dengan mengurangi investasi yang besar. Adapun tugas umum dari manajemen logistik adalah mengadakan keseimbangan antara biaya dan penghasilan untuk mencapai laba tertentu (Swastha,1990).

\section{Pemilihan Vendor Ekspedisi}

Menurut Jan Lizbetin, Lenka Cerna, dkk (2015), Ada kriteria berbeda untuk evaluasi pemasok di lingkungan pasar yang sebenarnya dan digunakan oleh perusahaan. Metode pertanyaan (pertanyaan yang tidak terstandardisasi) khusus bentuk wawancara mendalam dengan praktisi digunakan untuk menentukan dan memilih kriteria untuk evaluasi pemasok.

Kompilasi kriteria untuk evaluasi pemasok didasarkan pada wawancara pribadi dengan para praktisi.

- Harga - kepastian harga, perjanjian - berapa banyak pembeli harus membayar dan dalam periode apa. Harga mewakili harga pembelian layanan untuk satu unit jumlah yang dikirimkan.

- Kualitas - menyediakan kualitas layanan yang dapat direalisasikan. Pemasok dapat menjamin kualitas layanan mereka dengan cara yang berbeda: sertifikat mutu, jumlah keluhan hingga jumlah total layanan yang disediakan.C

- Keandalan - tenggat waktu (waktu pengiriman) kepatuhan.

- Waktu pengiriman - ini merupakan periode dari menerima pesanan oleh pemasok untuk pelaksanaan layanan tertentu.

- Fleksibilitas - jika ada permintaan untuk perubahan jumlah layanan yang disediakan, kriteria ini menunjukkan kesediaan pemasok untuk beradaptasideng an perubahan dan ekspresi kemampuan untuk memenuhi pesanan yang diterima pada waktunya.

Istilah lead time biasa digunakan dalam sebuah industri manufaktur, artinya adalah waktu yang diperlukan oleh perusahaan untuk memenuhi pesanan atau jumlah waktu yang berlalu antara ketika sebuah proses dimulai dan kapan selesai.

\section{Metode Topsis}

Metode TOPSIS Metode TOPSIS (Technique for Order Preference by Similarity to Ideal Solution) didasarkan pada konsep, dimana alternatif terpilih yang baik tidak hanya memiliki jarak terpendek dari solusi ideal positif yaitu memaksimalkan kriteria manfaat dan meminimalkan kriteria biaya, namun juga memiliki jarak terpanjang dari solusi ideal negatif yaitu memaksimalkan kriteria biaya dan meminimalkan kriteria manfaat. (Rouhani et al., 2012). TOPSIS digunakan dalam mengolah data untuk setiap alternatif yang ada di basis data, dimana pada akhirnya hasil dari pengolahan tersebut adalah berupa penentuan peringkat berdasarkan kriteria yang telah ditentukan, konsepnya sederhana dan mudah dipahami, komputasinya efisien, dan memiliki kemampuan untuk mengukur kinerja relatif dari alternatif-alternatif keputusan dalam bentuk matematis yang sederhana (Kelemenis, 2010.)

\section{Metode AHP (Analytical Hierarchy Process)}

AHP merupakan metoda pengambilan keputusan yang melibatkan sejumlah kriteria dan alternatif yang dipilih berdasarkan pertimbangan semua kriteria terkait (Saaty, 2004). Pada dasarnya, AHP merupakan metode yang digunakan untuk memecahkan masalah yang kompleks dan tidak terstruktur ke dalam kelompok-kelompoknya, dengan mengatur kelompok tersebut ke dalam suatu hirarki, kemudian memasukkan nilai numerik sebagai pengganti persepsi manusia dalam melakukan perbandingan relatif. 


\section{B. METODE PENELITIAN}

\section{Desain Penelitian}

Penelitian saat ini yang dilakukan adalah penelitian studi kasus yang dilakukan di PT. CS2 Pola Sehat. Studi kasus pada dasarnya meliputi analisis mendalam dan kontekstual terhadap situasi yang mirip dalam organisasi lain, yang mana sifat dan definisi masalah yang terjadi adalah serupa dengan yang dialami dalam situasi saat ini (Sekaran, 2006). Dalam penelitian ini dilakukan untuk mengetahui vendor terbaik yang digunakan untuk pendistribusian produk air minum dalam kemasan botol di PT.CS2 Pola Sehat.

\section{Pengumpulan Data}

\section{a. Kuesioner}

Kuesioner merupakan daftar pertanyaan tertulis yang telah dirumuskan sebelumnya yang akan responden jawab,biasanya dalam alternatif yang didefinisikan dengan jelas (Sekaran, 2006). Dalam hal ini, kuesioner yang telah dibuat akan diberikan kepada pemimpin perusahaan untuk kemudian dianalisa data-data tersebut. Responden dalam penelitian ini adalah Purchasing Director yang nantinya akan menentukan vendor apa yang akan digunakan.

\section{Analisis Data}

Penggunaan metode AHP diharapkan untuk menentukan bobot dari tiap kriteria dan uji konsistensi terhadap matriks perbandingan berpasangan. Apabila telah didapatkan bobot tiap kriteria dan bobot dari masing-masing vendor tersebut maka dapat dilanjutkan dengan penggunaan metode Fuzzy TOPSIS yang fungsinya bertujuan untuk meranking alternatif vendor yang ada saat ini. metode AHP mampu memecahkan masalah yang multi-objektif dan multi-kriteria yang berdasar pada preferensi dari setiap elemen dalam hierarki.

Sedangkan untuk pemilihan metode TOPSIS yaitu dikarenakan metode ini mempunyai konsep yang sederhana dan mudah dipahami, komputasinya efisien dan memiliki kemampuan untuk mengukur kinerja relatif dari alternative-alternatif keputusan dalam bentuk matematis yang sederhana (Ramanathan, 2001). Pada penelitian ini maka kriteria-kriteria yang digunakan dalam mengukur kinerja vendor untuk pengiriman produk AMDK Crystalline PET 600mL, diantara lain:

\section{Kualitas (Quality)}

Kualitas berkaitan dengan kemampuan dari tiap vendor untuk memenuhi setiap armada sesuai dengan standard yang ditentukan, yang nantinya diukur dalam skala penilaian perbandingan berpasangan. Dalam hal ini terdapat sub kriteria, meliputi:

a. Ketersediaan jumlah dan jenis armada yang sesuai (Q1)

b. Kondisi armada yang sesuai (Q2)

2. Harga (Cost)

Harga berkaitan dengan besarnya tarif yang diberikan tiap vendor yang diukur dalam skala penilaian perbandingan berpasangan.

\section{Pengiriman (Delivery)}

Pengiriman dalam hal ini berkaitan dengan kemampuan vendor untuk memenuhi permintaan dari customer tepat waktu yang diukur dalam skala perbandingan. Dalam hal ini terdapat beberapa sub kriteria, meliputi:

a. Kemampuan pemenuhan sesuai dengan tanggal yang ditentukan. (D1)

b. Kemampuan pemenuhan sesuai dengan jumlah yang telah ditentukan. (D2).

4. Fleksibilitas (Flexibility)

Fleksibilitas berhubungan dengan kemampuan vendor dalam memberikan informasi yang jelas dan benar sesuai dengan kebutuhan customer yang diukur dalam skala perbandingan. Terdapat sub kritera , meliputi:

a. Pemberian informasi terkait pengiriman (F1)

5. Responsif (Responssiveness)

Responsif berhubungan dengan keampuan vendor untuk menanggapi setiap masalah yang sedang terjadi baik saat pengiriman ataupun diluar pengiriman, diukur dalam skala perbandingan. Adapun terdapat sub kriteria, sebagai berikut:

a. Kemampuan merespon masalah/klaim (R1) 
b. Frekuensi terjadinya masalah/klaim. (R2)

Berikut ini merupakan langkah-langkah yang digunakan dalam menyelesaikan permasalahan dalam evaluasi kinerja vendor:

1. Menyusun struktur hirarki kriteria dan sub kriteria

2. Skala Nilai Perbandingan Berpasangan

3. Pengolahan data dilakukan dengan menggunakan metode AHP dan TOPSIS, namun sebelumnya diselesaikan menggunakan metode AHP terlebih dahulu.

Berikut ini merupakan langkah-langkah dalam pengolahan data menggunakan metode AHP, yaitu sebagi berikut:

a. Membuat matriks perbandingan berpasangan

b. Menormalisasikan bobot dari matriks perbandingan berpasangan

c. Menghitung nilai eigen value dan eigen vector

d. Melakukan uji konsistensi Indikator terhadap konsistensi diukur melalui indeks konsistensi (CI), dengan menggunakan persamaan (1):

$$
C I=\frac{\lambda_{\text {maks }}-n}{n-1}
$$

(1) AHP mengukur seluruh konsistensi penilaian dengan menggunakan consistency ratio (CR) dengan rumus seperti pada persamaan (2):

(2) Dimana,

$\mathrm{CR}=$ Consistency Ratio

$\mathrm{CI}=$ Consistency Index

$\mathrm{IR}=$ Indeks Random

Nilai $\mathrm{CR} \leq 0,1$ adalah konsisten jika tidak maka perlu dilakukan revisi

e. Menghitung rata-rata geometri (geometric mean)

Rata-rata geometrik dilakukan karena penilaian melibatkan banyak responden dan bertujuan untuk mendapatkan suatu nilai tunggal yang mewakili sejumlah responden pada persamaan (3) menunjukkan rumus rata-rata geometrik adalah sebagai berikut:

(3) $G M=\sqrt[n]{(x 1),(x 2), \ldots .,(x n)}$

Pada bagian ini memuat metode saja, tidak memuat bagan ataupun bagan alir.

\section{HASIL DAN PEMBAHASAN}

\section{Analisis Performa Kinerja Vendor}

Pada tahap ini akan dijelaskan bagaimana mengukur kinerja tiap vendor yang akan dipili menggunakan metode AHP dan TOPSIS.

Adapun data-data yang diperlukan diantaranya berupa data kuesioner terhadap kriteria-kriteria yang diuji, sebagai berikut:

1. Kriteria Kualitas

2. Kriteria Harga

3. Kriteria Pengiriman

4. Kriteria Fleksibilitas

5. Kriteria Responsif

Berikut merupakan tahapan dalam pemilihan vendor terbaik :

1. Membuat matriks perbandingan berpasangan yang menggambarkan kesinambungan antar setiap elemen yang ada didalamnya

Tabel Matriks Perbandingan Berpasanga

\begin{tabular}{|c|c|c|c|c|c|}
\hline Kriteria & Kualitas & Harga & Pengiriman & Fleksibilitas & Responsif \\
\hline Kualitas & 1 & 9 & 3 & 3 & 5 \\
\hline Harg & 0.111 & 1 & 1 & 0.143 & 0.2 \\
\hline Pengiriman & 0.333 & 1 & 1 & 0.2 & 1 \\
\hline Fleksibilitas & 0.333 & 7 & 5 & 1 & 3 \\
\hline Responsi & 0.2 & 5 & 1 & 0.333 & 1 \\
\hline
\end{tabular}


E ISSN 2621-6442

2. Menghitung bobot/ prioritas kepentingan dari masing-masing kriteria pada level pertama

Tabel Normalisasi Matriks Perbandingan Berpasangan

\begin{tabular}{c|c|c|c|c|c|c}
\hline Kriteria & $\mathbf{Q}$ & $\mathbf{C}$ & $\mathbf{D}$ & $\mathbf{F}$ & $\mathbf{R}$ & Average \\
\hline Q & 0.506 & 0.391 & 0.273 & 0.642 & 0.49 & $\mathbf{0 . 4 6}$ \\
\hline C & 0.056 & 0.043 & 0.091 & 0.031 & 0.02 & $\mathbf{0 . 0 4 8}$ \\
\hline D & 0.169 & 0.043 & 0.091 & 0.043 & 0.098 & $\mathbf{0 . 0 8 9}$ \\
\hline F & 0.169 & 0.304 & 0.455 & 0.214 & 0.294 & $\mathbf{0 . 2 8 7}$ \\
\hline R & 0.101 & 0.217 & 0.091 & 0.071 & 0.098 & $\mathbf{0 . 1 1 6}$ \\
\hline
\end{tabular}

3. Mengihitung consistency ratio dengan cara mencari eigen value maksimum dengan merata-ratakan nilai eigen value. Adapun hasil yang didapat adalah 5.048. Dari nilai tersebut maka dapat ditentukan nilai dari consistency index dan consistency ratio. Hasil yang didapat yaitu, CI 0.102 dan CR 0.09. Apabila nilai CR dibawah $10 \%$, maka responden tersebut sudah konsisten.

4. Menghitung bobot/ prioritas global kepentingan dari masing-masing kriteria yang telah ditentukan sebelumnya.

\begin{tabular}{|c|c|c|c|c|}
\hline Kriteria & Bobot Lokal & Sub Kriteria & Bobot Lokal & Bobot Global \\
\hline \multirow{2}{*}{ kualitas } & 0.46 & Q1 & 0.125 & 0.058 \\
\cline { 2 - 5 } & & Q2 & 0.875 & 0.403 \\
\hline Harga & 0.048 & & & 0.048 \\
\hline \multirow{2}{*}{ Pengiriman } & 0.089 & D1 & 0.875 & 0.078 \\
\cline { 2 - 5 } & & D2 & 0.125 & 0.011 \\
\hline Fleksibilitas & 0.287 & & & 0.287 \\
\hline Responsif & 0.116 & R1 & 0.1 & 0.012 \\
\cline { 2 - 5 } & & R2 & 0.9 & 0.104 \\
\hline Jumlah & $\mathbf{1}$ & & & $\mathbf{1}$ \\
\hline
\end{tabular}

5. Membangung matriks keputusan

\section{Tabel Normalisasi Matriks Tiap Alternatif}

\begin{tabular}{|c|c|c|c|c|c|c|c|c|}
\hline Alternatif & Q1 & Q2 & C & D1 & D2 & F & R1 & R2 \\
\hline Alt 1 & 3.73 & 0.14 & 1.7 & 0.62 & 4.42 & 3.32 & 10.9 & 5.43 \\
\hline Alt 2 & 18.6 & 0.68 & 2.55 & 1.04 & 92.8 & 0.55 & 65.1 & 13.6 \\
\hline Alt 3 & 11.2 & 1.35 & 5.11 & 1.04 & 92.8 & 5.53 & 152 & 054 \\
\hline Alt 4 & 18.6 & 2.03 & 15.3 & 3.12 & 6.19 & 3.32 & 7.24 & 0.39 \\
\hline Alt 5 & 26.1 & 0.23 & 1.7 & 15.6 & 30.9 & 1.11 & 65.1 & 0.91 \\
\hline Alt 6 & 1.24 & 1.35 & 1.02 & 1.04 & 30.9 & 1.11 & 65.1 & 1.36 \\
\hline Alt 7 & 7.46 & 0.23 & 0.73 & 9.37 & 10.3 & 0.37 & 21.7 & 13.6 \\
\hline Alt 8 & 1.87 & 0.14 & 25.5 & 21.9 & 92.8 & 2.21 & 4.34 & 2.72 \\
\hline Alt 9 & 18.6 & 1.35 & 15.3 & 1.04 & 30.9 & 0.37 & 10.9 & 0.68 \\
\hline Alt 10 & 11.2 & 4.73 & 35.7 & 9.37 & 10.3 & 3.32 & 5.43 & 1.36 \\
\hline Alt 11 & 1.24 & 1.35 & 15.3 & 1.56 & 92.8 & 2.21 & 109 & 10.9 \\
\hline Alt 12 & 1.87 & 0.23 & 5.11 & 1.04 & 7.73 & 1.11 & 65.1 & 0.54 \\
\hline Alt 13 & 22.4 & 0.14 & 2.55 & 0.78 & 5.15 & 0.28 & 7.24 & 1.36 \\
\hline Allt 14 & 1.87 & 2.7 & 20.4 & 12.5 & 30.9 & 5.53 & 5.43 & 8.15 \\
\hline Alt 15 & 1.24 & 0.23 & 2.55 & 6.24 & 155 & 1.11 & 21.7 & 0.91 \\
\hline Bobot Global & 0.06 & 0.40 & 0.05 & 0.08 & 0.01 & 0.29 & 0.01 & 0.10 \\
\hline
\end{tabular}


6. Membangung matriks keputusan terbobot

Tabel Normalisasi Matriks Bobot Tiap Alternatif

\begin{tabular}{||c|c|c|c|c|c|c|c|c||}
\hline Alt & Q1 & Q2 & C & D1 & D2 & F & R1 & R2 \\
\hline Alt 1 & 0.22 & 0.05 & 0.08 & 0.05 & 0.05 & 0.95 & 0.13 & 0.57 \\
\hline Alt 2 & 1.07 & 0.27 & 0.12 & 0.08 & 1.03 & 0.16 & 0.75 & 1.42 \\
\hline Alt 3 & 0.64 & 0.55 & 0.25 & 0.08 & 1.03 & 1.59 & 1.76 & 0.06 \\
\hline Alt 4 & 1.07 & 0.82 & 0.74 & 0.24 & 0.07 & 0.95 & 0.08 & 0.04 \\
\hline Alt 5 & 1.5 & 0.09 & 0.08 & 1.21 & 0.34 & 0.32 & 0.75 & 0.09 \\
\hline Alt 6 & 0.07 & 0.55 & 0.05 & 0.08 & 0.34 & 0.32 & 0.75 & 0.14 \\
\hline Alt 7 & 0.43 & 0.09 & 0.04 & 0.73 & 0.11 & 0.11 & 0.25 & 1.42 \\
\hline Alt 8 & 0.11 & 0.05 & 1.23 & 1.7 & 1.03 & 0.64 & 0.05 & 0.28 \\
\hline Alt 9 & 1.07 & 0.55 & 0.74 & 0.08 & 0.34 & 0.11 & 0.13 & 0.07 \\
\hline Alt 10 & 0.64 & 1.91 & 1.72 & 0.73 & 0.11 & 0.95 & 0.06 & 0.14 \\
\hline Alt 11 & 0.07 & 0.55 & 0.74 & 0.12 & 1.03 & 0.64 & 1.26 & 1.13 \\
\hline Alt 12 & 0.11 & 0.09 & 0.25 & 0.08 & 0.09 & 0.32 & 0.75 & 0.06 \\
\hline Alt 13 & 1.29 & 0.05 & 0.12 & 0.06 & 0.06 & 0.08 & 0.08 & 0.14 \\
\hline Alt 14 & 0.11 & 1.09 & 0.98 & 0.97 & 0.34 & 1.59 & 0.06 & 0.85 \\
\hline Alt 15 & 0.07 & 0.09 & 0.12 & 0.49 & 1.72 & 0.32 & 0.25 & 0.09 \\
\hline
\end{tabular}

7. Menentukan Matriks Solusi Ideal Positif dan Solusi Ideal Negatif

Tabel Solusi Ideal Positif dan Solusi Ideal Negatif

\begin{tabular}{c|c|c|c|c|c|c|c|c}
\hline $\begin{array}{c}\text { Solusi } \\
\text { Ideal }\end{array}$ & Q1 & Q2 & C & D1 & D2 & F & R1 & R2 \\
\hline $\mathrm{A}^{*}$ & 0.072 & 1.906 & 1.721 & 1.697 & 1.715 & 1.587 & 1.759 & 1.415 \\
\hline A- & 1.502 & 0.054 & 0.035 & 0.048 & 0.049 & 0.079 & 0.05 & 0.04 \\
\hline
\end{tabular}

8. Menentukan Jarak Antara Nilai Setiap Alternatif

\begin{tabular}{|c|c|c|}
\hline Alternatif & Di* $^{*}$ & Di- \\
\hline Alt 1 & 0.329 & 0.104 \\
\hline Alt 2 & 0.324 & 0.14 \\
\hline Alt 3 & 0.179 & 0.261 \\
\hline Alt 4 & 0.352 & 0.045 \\
\hline Alt 5 & 0.197 & 0.196 \\
\hline Alt 6 & 0.103 & 0.297 \\
\hline Alt 7 & 0.187 & 0.212 \\
\hline Alt 8 & 0.284 & 0.118 \\
\hline Alt 9 & 0.186 & 0.298 \\
\hline Alt 10 & 0.257 & 0.145 \\
\hline Alt 11 & 0.096 & 0.36 \\
\hline Alt 12 & 0.217 & 0.194 \\
\hline Alt 13 & 0.171 & 0.22 \\
\hline Alt 14 & 0.079 & 0.332 \\
\hline Alt 15 & 0.216 & 0.173 \\
\hline
\end{tabular}


9. Menghitung Kedekatan Relatif Terhadap Solusi Ideal

\begin{tabular}{|c|c|}
\hline Alternatif & Result \\
\hline Alt 1 & 0.240 \\
\hline Alt 2 & 0.302 \\
\hline Alt 3 & 0.592 \\
\hline Alt 4 & 0.114 \\
\hline Alt 5 & 0.499 \\
\hline Alt 6 & 0.743 \\
\hline Alt 7 & 0.532 \\
\hline Alt 8 & 0.293 \\
\hline Alt 9 & 0.615 \\
\hline Alt 10 & 0.361 \\
\hline Alt 11 & 0.790 \\
\hline Alt 12 & 0.472 \\
\hline Alt 13 & 0.564 \\
\hline Alt 14 & 0.807 \\
\hline Alt 15 & 0.445 \\
\hline
\end{tabular}

Penentuan bobot pada metode AHP sebelumnya tentu akan mempengaruhi beberapa alternatif yang akan dipilih.

Pada perhitungan dengan metode TOPSIS yang telah dilakukan didapatkan hasil bahwa vendor yang memiliki nilai paling tinggi terdapat pada vendor Japung dengan nilai bobot keseluruhan sebesar 0.807 . Kemudian alternatif kedua dengan nilai bobot sebesar 0.790 didapatkan oleh vendor CHM. Selanjutnya untuk posisi dengan ranking ketiga didapatkan oleh vendor KBM dengan total nilai bobot sebesar 0.743. Pada posisi ranking nomor empat didapatkan oleh vendor SMG dengan total nilai bobot sebesar 0.615. Dan untuk posisi ranking nomor lima didapatkan oleh vendor GLL dengan total nilai bobot sebesar 0.592.

Penentuan vendor terpilih didasarkan dari keputusan Purchasing Director, yang dalam hal ini menentukan lima ranking teratas dari hasil peniliaian.

\section{KESIMPULAN}

\section{Kesimpulan}

Berdasarkan tujuan penelitian serta hasil pembahasan data yang telah diuraikan dengan mengacu pada beberapa teori dari penelitian ini, maka hasil penelitian ini dapat disimpulkan sebagai berikut:

- Penerapan metode AHP dan Fuzzy TOPSIS untuk pengambilan keputusan pada saat memilih vendor yang terbaik merupakan alternatif yang cukup baik dibandingkan dengan cara pengambilan keputusan sebelumnya.

- Kriteria utama yang memiliki nilai bobot cukup besar yaitu, kualitas, fleksibilitas dan responsif.

- Pemilihan vendor pada penelitian ini terpilih tiga alternatif vendor yang memiliki bobot paling tinggi, diantaranya Japung, CHM dan KBM, dengan memperoleh nilai bobot masing-masing sebesar , 0.807 , 0.790 , dan 0.743 .

\section{Saran} berikut:

Berdasarkan kesimpulan diatas, maka saran yang dapat diajukan pada penelitian ini adalah sebagai

1. Penelitian selanjutnya dapat membandingkan metode MCDM yang lainnya sehingga diharapkan adanya perbandingan dari metode saat ini. Selain itu dapat menambah alternative kriteria yang digunakan sesuai dengan kebutuhan perusahaan.

2. Vendor saat ini harus lebih memperhatikan masalah kualitas armada yang dimiliki, waktu pengiriman, fleksibilitas, serta kecepatan dalam menghadapi masalah setiap pelanggan.

\section{DAFTAR PUSTAKA}

[1]. Arikunto, S. 2006. Metode Penelitian Kualitatif. Jakarta: Bumi Aksara. 
[2]. Ellram, Lisa M, Tate, Wendy L, dan Billington, Corey. 2008. Offshore outsourcing of professional services: A transaction cost economics perspective. Journal of Operations Management.

[3]. Gaspersz,Vincent,2006,Sistem Manajemen Kinerja Terintergrasi Balanced Scorecard dengan Six Sigma untuk Organisasi Bisnis dan Pemerintah, Gramedia Pustaka.

[4]. Jharkharia, S., dan Shankar, R., 2007, "Selection Of Logistics Service Provider An Analytic Network Process (ANP) Approach" International Journal Management Science, Singapore.

[5]. Kelemenis, A., dan Askounis, D., 2010, A new TOPSIS-basedmulti-criteria approach to personnel selection, Expert Systems With Applications Vol.37 (2010) 4999-5008.

[6]. McCarthy, I., \& Anagroustou, A. (2004). The impact of outsourcing on the transaction costs and boundaries of manufacturing. International Journal of Production Economics, 88(1), 61-71.

[7]. Pujawan, I. N., Mahendrawati, E. R., 2010, Supply Chain Management, Penerbit Gunawidya: Surabaya.

[8]. Saaty, T. L., 1980, The Analytic Hierarchy Process, McGraw-Hill.

[9]. Saaty, T. L., 2005, Theory and Applications of the Analytic Network Process: Decision Making with Benefits, Opportunities, Costs, and Risks, RWS Publications, Pittsburgh.

[10]. Sugiyono, 2009, Metode Penelitian Kuantitatif, Kualitatif dan R\&D, Bandung : Alfabeta.

[11]. Siahaya, Willem, 2013, Sukses Supply Chain Management, Jakarta: In Media.

[12]. Vijayvargiya, A., Dey, A. K. (2010). An analytical approach for selection of a logistics provider. Management Decision, 48(3): 403-418.

[13]. Zeithaml, V.A., M.J. Bitner, D.D. Gremler. 2013. Services Marketing: Integrating Customer Focus Across the Firm 6 thed. Mc.Graw-Hill. Boston. 